\title{
Önkormányzati választás Szegeden, 2019
}

\author{
FÁBIÁN GYÖRGY1
}

\section{ABSZTRAKT}

A 2019-es helyi, önkormányzati választás az adott politikai konstellációban kiemelkedett a szokásos másodrendü (second-order) választások sorából. Különösen igaz ez Szegedre, ahol az ellenzék az országos politikai helyzettel szemben hosszú idő óta birtokolta a helyi hatalmat. Ennek a helyzetnek a megváltoztatására, eröfölényüket kihasználva a kormánypártok - a várost csatatérnek tekintve - minden eszközt bevetố rendkívül erôteljes kampányt folytattak. Ez azonban nem járt sikerrel, az eredmények alapján kontraproduktívnak minősíthető. A regnáló polgármester és a városvezetés minden eddiginél nagyobb arányú győzelmet aratott. Ennek alapvetô oka a helyi politikát a pártharcokból kivonó, pártérdekeket felülíró, a város érdekeit ellenszélben is sikeresen és hitelesen képviselö, teljes körü, az egész ellenzéket magában foglaló együttmúködést megvalósító várospolitika, amelyet a 2002 óta hivatalban lévő polgármester személye szimbolizál és testesít meg.

KULCSSZAVAK: önkormányzati választás, Szeged, választási kampány, polgármester- és képviselőjelölés, választási eredmények.

\section{ABSTRACT}

\section{The 2019 local elections in Szeged}

The 2019 local, municipal election outclasses the second-order elections in the given political constellation. This is especially true in the case of Szeged, where the opposition - unlike the situation at the national level - has the power for a long time. To change this situation, the governing parties, taking advantage of their dominant position - and using all means - conducted a very vigorous campaign, changing the city into a battlefield. According to the results, the governemt's attempt was not successfull, it was rather contraproductive. The reigning mayor and city management won an unprecedented victory. The root cause of it is a special urban policy which extracted the local politics from the partyfights and overrode party interests, and which represented the interests of the city succesfully and with credibility even against cross-wind. Based on the cooperation of the entire opposition the implemented urban policy is symbolized by and embodied in the person of the mayor in office since 2002.

KEYWORDS: municipal election, Szeged, election campaign, mayor and representatives nominations, election result.

${ }^{1}$ Szegedi Tudományegyetem, Állam és Jogtudományi Kar, Politológiai Tanszék, c. egyetemi tanár, gyfabian@polit.u-szeged.hu 


\section{Bevezetés}

A 2019-es önkormányzati választás több szempontból is különös jelentőséggel bírt. Ez volt az első, amely ötéves ciklust zárt le. Másrészt mind a kormánypárt, mind az ellenzék számára a szokásos second-order (másodlagos) jellegű választás jelentősége megnőtt azzal, hogy az adott politikai térben a választás eredménye befolyásolhatja a következő parlamenti választás sorsát. ${ }^{2}$ A helyi hatalom birtoklása ugyanis egyre nagyobb szerepet játszik a parlamenti választások eldöntésében.

Ebben a tekintetben a fővárosi mellett a szegedi választás eredménye vált kiemelt fontosságúvá. Itt ugyanis négy cikluson keresztül 2002 óta Dr. Botka László (MSZP) a polgármester, aki egy kivétellel (2010-2014), négy választást nyerve baloldali-liberális többséggel irányította a várost. Szeged tehát az országos trendtől eltérő irányú fejlődést testesített meg. Az önkormányzati választásokon 2006 óta elsöprő győzelmeket arató FIDESZ Szegeden nem tudta megszerezni a helyi hatalmat. Minden alkalommal mást indított a baloldali polgármester ellen, sikertelenül (Fábián 2013). 2014-ben az MSZP-DK-EGYÜTT-PÁRBESZÉD-SZEGEDÉRT jelöltjeként a voksok 58,22\%-kal, csaknem 14000 szavazattal többet kapva nyert Kothencz János, a FIDESZ-KDNP-L.É.T EGYESÜLET jelöltje ellen (36,88\%). Ami még ennél is súlyosabban érintette a kormánypártokat, a húsz egyéni körzetből tizenhetet a baloldali-liberális összefogás jelöltjei nyertek meg. Ez azt jelentette, hogy a jobboldal elvesztette az előző ciklusban meglévő közgyűlési többségét. A FIDESZ-KDNP 6, a Jobbik és az LMP 1-1 kompenzációs helyhez jutott.

Ez a helyzet arra késztette a kormánypártot, hogy mindent elkövessen a város politikai térképének megváltoztatásáért. Ez helyi szervezetének teljes újjászervezését, a pártközpontból, a pártigazgató vezetésével történő közvetlen irányítást, permanens kampányt jelentett a regnáló városvezetés ellehetetlenítése érdekében. Ennek érdekében hatalmas anyagi, szellemi, személyi erőforrásokat összpontosítottak Szegedre 2014-től kezdődően. A két legfontosabb változás ebben a tekintetben az egyetem vezetésének megszerzése - ami a városvezetéssel addig normálisnak mondható együttműködés megbomlásához vezetett - valamint a nagy múltú, nagy hatású megyei lap, a Délmagyarország c. napilap megszerzése és kormánypropaganda-lappá alakítása volt. Az egyetem rektora a FIDESZ-KDNP által támogatott független jelölt támogatására szólított fel, a lap pedig tájékoztatás helyett mindent megtett a városvezetés és elsősorban Botka László lejáratására. Ez a folyamat a hivatalosan 50 nappal a választás előtt, 2019. augusztus 24-én induló kampányidőszakban érkezett a tetőpontjára. Így a baloldali-liberális városvezetés ellenére, a választási kampány

${ }^{2}$ A szakirodalom azokat a választásokat tartja second order jellegünek (Reif-Schmitt 1980), amelyek nem a politika bináris kódja mentén döntenek (ki kerül hatalomra és ki ellenzékbe). Ilyenek a helyi, regionális, uniós választások. 
aszimmetriája Szegeden is látványosan nyilvánult meg, bár az országosnál kevésbé lehetett érvényesíteni. A helyi hatalom birtokában ugyanis itt több eszköz állhatott az aszimmetria ellensúlyozására, mint ott, ahol az önkormányzatok a kormányzó párt eszközeivé váltak. A szegedi önkormányzat a helyi televízió, a szeged.hu portál, a Szegedi Tükör segítségével próbált a központilag irányított hiteltelenítéssel, rágalmakkal szembeszállni.

Szegeden nem a mostani választásra állt össze a demokratikus erők együttműködése. Az elmúlt tíz évben az országos helyzettől eltérően már 2010-ben a civilekkel történő összefogás jegyében az MSZP-ÖSSZEFOGÁS SZEGEDÉRT ernyőszervezet jelöltjeként indult Botka László, és az egyéni választókerületek képviselőjelöltjei is közös jelöltek voltak. Ez azt jelezte, hogy Szeged már ekkor megpróbálkozott a helyi választást kivonni az országos politikai térből, a pártcsatározásokból, a helyi ügyekre koncentrálva. A jobboldalnak természetesen - helyi gyengeségét ellensúlyozva - éppen az volt az érdeke, hogy az országos kormányváltó hangulatot kihasználva szerezze meg a helyi hatalmat. A baloldal akkor még legnagyobb pártja, az MSZP stratégiája részben sikert hozott. A megyei jogú városok közül egyedül sikerült a polgármesteri pozíciót elnyerni, ugyanakkor a képviselőtestületben nem szerzett többséget. A 2010-2014 közötti várospolitikája azonban ellenszélben is sikeresnek bizonyult, amit 2014 visszaigazolt. Ekkor tovább szélesítve az együttműködést, már pártokkal is összefogva Botka László és csapata földcsuszamlásszerű győzelmet aratott és biztos képviselőtestületi többséggel irányíthatta a várost.

\section{A kampány}

Ilyen előzmények által is meghatározott helyi politikai térben kezdődött a hivatalos választási kampány augusztus 24-én. A kormánypárt ellenzéke a korábbinál is határozottabban építette kampányát a lokalitásra, a „Szegediségre”, a pártoktól való távolságtartásra. Ezt hangsúlyozandó, szimbolikus jelentése volt annak, hogy Botka László, az Összefogás Szegedért Egyesület jelöltjeként indult a polgármesteri pozícióért összellenzéki támogatással, a képviselőjelölteket és kompenzációs listát indító jelölőszervezetek sorrendje pedig az Összefogás Szegedért Egyesülettel indul, ezt követi az MSZP, a Momentum, a Demokratikus Koalíció, az LMP és a Jobbik. A pártok külön-külön a kampányban nem szerepeltek, jelöltjeik párthovatartozása sem jelent meg. Az Összefogás kampánya Szegedről szólt, fő jelszava az „Építsük tovább Szegedet”, valamint az volt, hogy „meg fogjuk őrizni városunk önállóságát és függetlenségét”. Ezen kívül a Szegedet a legzöldebb magyar várossá, a szolidaritás városává teszszük kampányszlogenek jelentek még meg. A szegediség jegyében a városvezetés Szeged szabad királyi városi státusa visszaadásának 300 éves évfordulójának megünneplésével zárta október 12-én kampányát. 12 pontban megfogalmazták a következő öt év feladatait is, amelyet minden háztartásba eljuttattak (szeged.hu). 
A köztéri hirdetések, óriásplakátok elérhetőségében, a helyi sajtóban való megjelenésben, a telefonos, szórólapos kampányolásban lévő óriási különbségek miatt az Összefogás kampánya visszafogottabbnak tűnt. Elsősorban képviselőjelöltjeik választóikkal történő személyes találkozóin, a választókörzetek ügyeivel foglalkozó aprómunkán keresztül jelentek meg a kampányban. Az önkormányzati választás amennyire lehetséges - eltávolítása az országos politikai tértől tartható kampányuk fő elemének.

A FIDESZ-KDNP első és legfontosabb feladata egy megfelelő, győzelemre esélyes személy kiválasztása volt a hivatalban lévő polgármesterrel szemben. Ezért egy független, technokrata, az üzleti szférából, és nem a politikából jövő, a párthoz nem szorosan kapcsolódó jelöltet indítottak, Nemesi Pál, a Ferroép Zrt. menedzsere, résztulajdonosa, a Csongrád Megyei Kereskedelmi és Iparkamara elnöke személyében. A jelölt kiválasztása jónak mondható, hiteles személyi alternatívát jelenthetett a regnáló polgármesterrel szemben. Ezt erősítette az is, hogy programja alapvetően a város gazdasági, infrastrukturális fejlesztésére és a szegediségre épült (Délmagyarország, 2019. október 12.). Két legfontosabb hívószava a „Nekünk Szeged az első”, és a harmadik híd megépítését ígérő „Október 13-án hidat építünk” (Délmagyarország, 2019. szeptember 7.) kampányának pozitív és nem negatív hangsúlyt adott. Emellett a változás szükségességének hangoztatása Szeged érdekében volt a fő mondanivalója. Kampányeszközei között megjelent a „Párbeszéd Szegedért” kérdőíves felmérés, 72000 helyre postázva, ingyenes válaszborítékkal, hogy a szegediek akarata alapján határozza meg a város irányítását, családi hétvégék szervezése, lakásfórumok (Délmagyarország, 2019. szeptember 3.). A kampányban való személyes részvétele, megjelenései, mondanivalójának elsősorban szakmai kérdésekre irányuló, mérsékelt hangneme is azt tükrözte, hogy reális alternatívát jelenthet az addigi városvezetéssel, várospolitikával szemben.

Mindezt azonban ellenpontozta az, hogy az ôt támogató FIDESZ-KDNP helyileg nem tudott elvonatkoztatni országos politikájának, propagandájának az ellenzék gyengeségére, ellenségnek feltüntetésére, megalázására alapozott arrogáns, agresszív, személyek ellen irányuló, lejáratásra összpontosító, a hazugságoktól, rágalmazástól sem visszariadó, sokszor minősíthetetlen stílusától, hangnemétől. Így a kampányt elsősorban Botka László személyére, lejáratására, hitelességének aláásására összpontosították. Postaládába bedobott hamis levelekkel támadták a polgármestert. Nem vették figyelembe, hogy Szegeden nem a gyenge ellenzékkel, hiteltelen politikával, személlyel, hanem a várost 17 éve irányító, hiteles - ha nem is hibátlan - városvezetéssel állnak szemben. A kampányidőszakban mind a Délmagyarországot, mind a Szegedma.hu portált az egyoldalú, szélsőséges, a várost csatatérnek tekintő hangnem jellemezte, megkérdőjelezve a várost minden szegedi érdekében irányítani kívánó, a helyi lakosságot pártállástól függetlenül élni és dolgozni, érvényesülni engedő, konszenzuális, nyugalmat, békét biztosítani kívánó vá- 
rosvezetés hitelességét. A hivatalos kampány első napján a Délmagyarország „Fogy a levegő Botka körül” címlappal jelent meg (Délmagyarország, 2019. augusztus 24), és a kampányban végig Botka gyengeségét, meggyengülését hangsúlyozták, a városvezetés elfáradásáról és arról beszéltek, hogy nem a szegediek érdekeit képviseli (Délmagyarország, 2019. szeptember 20). Gyengesége miatt eladta a várost Gyurcsánynak, az összefogás a szélsőbaltól az antiszemitákig terjedő szivárványkoalíció, amilyen városvezetésre még sehol sem volt példa. Közpénzek eltulajdonításáról, az új uszoda bukásáról, a polgármester leválthatóságának lehetőségéről szóló közvéleménykutatásról szóló hírek uralták a tájékoztatást. Az egyik önkormányzati cég beszállítója vezetőjének egy női alkalmazottnak adott állítólagos pofonja miatt napokig a nőverős botrány uralta híreiket (Délmagyarország, 2019. október 4.), a polgármester és egyik jelöltje nőverőként jelent meg egy molinón. A portálon megjelent a visszaszámláló óra, amely megmutatta, mennyi idő maradt még hátra Botka uralmából, hogy már csak napjai vannak hátra Szeged Jobbikkal kollaboráló polgármesterének. A gyülöletkampány mélypontja a Szegedma.hu portálon megjelenő, a Hitler bukása című film jeleneteire montírozott feliratok Botka László: a bukás Szegeden 2019 címmel (szegedma.hu).

A FIDESZ kampány másik a központi kampányból eredo, Szegedre is alkalmazott eleme volt a migránsbefogadás, a korábbinál enyhébben folyó „sorosozás”, valamint az, hogy a város fejlődésének elsődleges biztosítéka, hogy a kormány és az önkormányzat ugyanannak a politikai erőnek a kezében legyen. (Ez önmagában is az önkormányzatiságnak, a helyi hatalom autonómiájának, a szubszidiaritás elvének tagadását jelenti.) A kormányzati tényezők, szereplők szegedi kampányban való megjelenése is az említett két elemet erősítette. A FIDESZ kongresszusán Orbán Viktor Szegedről szólva kijelentette, a város nem fejlődik és migránsváros lesz, ha marad a jelenlegi vezetés. Ez a gondolat uralta a kampányt: „Szeged lesz az első számú betelepülési célpont", Soros szervezet érkezik Szegedre, mert az Amnesty International Freedom Clubot akar nyitni. Nemesi Pál Pesten egyeztetett Orbán Viktorral címmel fényképes cikk jelent meg szeptember 14-én a megyei lapban (Délmagyarország, 2019. szeptember 14.). Nem volt véletlen az sem, hogy Kövér László első kampányútja Szegedre vezetett. Szíjjártó Péter két alkalommal is kampányolt Szegeden. Hangoztatta, hogy a város lemaradt a fejlődésben, a jelenleginél nagyobb fogadókészség kellene az együttmúködéshez, és akkor Szeged lehet a jövő nyertese. Pintér Sándor szegedi látogatásakor kijelentette, hogy a kormány garantálja a közbiztonságot. Kósa Lajos Nemesi Pállal tartott sajtótájékoztatót. Ezek beletartozhatnak egy kampány keretébe, de jelzik a kiemelt figyelmet a szegedi kampányra. A fó mondanivaló az volt, hogy a város csak kormányzati támogatással, a kormánnyal való együttmúködéssel tud fejlődni. A választási eredményekből viszont levonható az a következtetés, hogy kampányuk kettősége, a negatív kampány túlsúlya, a polgármesterváltó hangulatszítása sikertelennek bizonyult. 


\section{Jelölések, jelöltek}

A polgármesteri tisztségért heten kívántak elindulni, azonban csak öten tudták öszszegyűjteni a szükséges ajánlásokat. Így Dr. Botka László (Összefogás Szegedért Egyesület), Nemesi Pál (független) a FIDESZ-KDNP támogatásával, dr. Szabó Bálint (független), Lauer István (független) és Dr. Bartha László (Tisza Koalíció), Szeged 1998-2012 közötti Fideszes polgármestere indulhatott a tisztségért. Utóbbi azonban nem sokkal a választás előtt visszalépett, azzal az indokkal, hogy a változás esélyét növelje. Szabó Bálint régóta radikális eszközöktől sem visszariadó támadója a polgármesternek, de a kampányban Nemesi Pált is visszalépésre szólította fel. Laurer István indulása személyes sértődöttségből következett be. ő az előző ciklusban az MSZP egyéni körzetet megnyerő képviselője volt, akit a szélesebb összefogás miatt nem tudtak újra indítani.

Egyéni képviselőjelöltként minden eddiginél kevesebben, 85-en indultak, húszan nem tudták a szükséges ajánlásokat összegyüjteni. 2014-ben még 107 volt az induló jelöltek száma. 2019-ben a legtöbb induló jelölt öt, a legkevesebb három volt. A jelöltek számának fokozatos csökkenése tehát tovább folytatódott. A létszámcsökkenés ezúttal azzal is összefüggött, hogy az LMP és a Jobbik csatlakozott a várost vezető koalícióhoz. Az Összefogás Szegedért Egyesület és a FIDESZ-KDNP mind a 20 körzetben indult, a Tisza Koalíció 18, a Független Városi Szövetség (FVSZ)-Magyar Egyesület 14, a Mi Hazánk 6 képviselőjelöltet indított, heten pedig függetlenként indultak. A jelöltek többsége új volt, mindössze 19 volt olyan, aki korábban már indult képviselőjelöltként. Az Összefogás tíz helyen indította el 2014-ben győztes jelöltjét, hét győztes jelöltje nem indult el, kilenc új jelöltje volt, egy pedig 2014-ben a Jobbik színeiben indult. A FIDESZ-KDNP három győztes jelöltje közül kettőt indított el, rajtuk kívül három korábbi induló ismét próbálkozott. Ők tehát 15, többségében kevésbé ismert jelöltet indítottak. Kompenzációs listát négy szervezet tudott állítani, az Összefogás Szegedért Egyesület, a FIDESZ-KDNP, az FVSZ-Magyar Egyesület és a Tisza Koalíció.

Az önkormányzati választáson a részvétel rendszerint alacsonyabb, mint a parlamentin. 2019-ben az országos politikára nagyobb hatást gyakorló, megnövekedett tétet a részvételi arány emelkedése is jelezte. Az országos részvételi arány 48,58\%ra emelkedett a 2014-es 44,3\%-ról. Szegeden a választási aktivitás általában meghaladta az országost, 2019-ben pedig rekordmagasságú volt, először érte el az 50\%-ot. 2014-ben 46,65\%, 2019-ben 51,4\% volt a részvétel.

\section{Az eredmények}

A polgármesteri székért végül négy jelölt indult el. Dr. Botka László az Összefogás Szegedért Egyesület jelöltje 40858 (60,56\%), Nemesi Pál (független) 24 568-at (36, 
41\%) szavazatot kapott. Dr. Szabó Bálint (független) 1186 (1,76\%), Lauer István (független) 857 (1,2\%) vokshoz jutott. A regnáló ellenzéki polgármester ötödik ciklusára kapott felhatalmazást, minden eddigit felülmúló eredménnyel. 2014-hez képest is növelte előnyét, több mint 16000 szavazattal kapott többet a FIDESZ által támogatott jelöltnél. Ha a kapott szavazatok számát vetjük össze a két választáson, akkor azt látjuk, hogy a szavazótáborokban nem történt lényeges elmozdulás. Botka csaknem 3000 vokssal kapott többet 2019-ben, ami nagyjából megegyezik az előző választáson induló Jobbikos és LMP-s jelöltre eső szavazatokkal. Nemesi Pál függetlenként mintegy 1000 szavazattal volt képes megnövelni a jobboldalra eső támogatást. A két másik jelölt közül Szabó inkább jobbról, Lauer inkább balról vihetett el voksokat, egyik sem befolyásolta számottevően a két tábor erőviszonyait.

A képviselőtestület összetételét meghatározó egyéni választókerületek eredménye a sok új jelölt, a teljeskörü, polgármestert támogató összefogás miatt bizonytalanabb, kiszámíthatatlanabb volt. Kérdéses volt az átszavazás az MSZP-től a Jobbikig terjedő együttműködésben. Az eredmények viszont azt igazolták, hogy a jelöltek személyénél sokkal nagyobb jelentősége volt annak, hogy a polgármestert, a városvezetést képviselő koalíció, vagy az azt leváltani kívánó tábor jelöltjéről van szó. Így a 20 kerületből 18-at, az előző választásnál eggyel több körzetet szerzett meg a polgármesteri többség. A FIDESZ 2014-ben győztes két jelöltje ismét nyerni tudott. A 18 közül 17-et abszolút többséggel szerzett meg az összefogás jelöltje, ebből nyolcat 60\%-nál magasabb szavazataránnyal. A legjobb eredményt a VIII. választókerület jelöltje, dr. Kozma József érte el, 67,97\%-kal. A harmadik kerületben volt a legszorosabb verseny, Dr. Simon-Fiala Donát (48,69\%) és dr. Csorba Ágnes (41,57\%) között, ahol kevesebb, mint 300 szavazat döntött. A két korábbi győztes FIDESZ jelölt is meggyőző fölénnyel, abszolút többséget elérve győzött, Kothencz János a XV. választókerületben csaknem 800 szavazatnyi előnnyel, 60\% feletti eredménnyel. A választók tehát nem tettek különbséget, nem is tudták az összefogás jelöltjeinek párthovatartozását, nem pártokra, hanem egyértelműen a polgármesterre, az addigi várospolitika folytatására voksoltak az egyéni választókerületekben is. Ezt támasztja alá az is, ahogy azokban a kerületekben alakultak az eredmények, ahol mindkét oldalon új, szinte ismeretlen jelöltek indultak. A IX. kerületben Molnár Zoltán több mint 1000 szavazattal verte meg Kárpáti Zoltánt, a XVII.-ben Urbán Tamás szintén csaknem ugyanennyivel győzött. Különösen figyelemre méltó ebben az összefüggésben a XVIII. kerület, ahol az ismertebb, korábban is itt indult Német Ferencet több mint 500 vokssal verte meg Mihálik Edvin. 
www. metszetek.unideb.hu

TEMATIKUS TANULMÁNYOK - Önkormányzati választások elméletben és gyakorlatban

1. táblázat. Az egyéni választókerületek eredményei

\begin{tabular}{|r|l|r|l|c|}
\hline & ÖSSZEFOGÁS SZEGEDÉRT & $\begin{array}{c}\text { Eredmény } \\
\text { szavazat (\%) }\end{array}$ & FIDESZ-KDNP & $\begin{array}{c}\text { Eredmény } \\
\text { szavazat (\%) }\end{array}$ \\
\hline I. & Komjáti Zoltán & $1362(40,12)$ & Mihálffy Béla & $1943(57,23)$ \\
\hline II. & Dr. Fodor Antal & $1739(52,67)$ & Korponyai Ernő & $1048(31,85)$ \\
\hline III. & Dr. Simon-Fiala Donát & $1929(48,69)$ & Dr. Csorba Ágnes & $1647(41,57)$ \\
\hline IV. & Ménesi Imre & $1855(65,1)$ & Batári Dávid & $849(29,8 \%)$ \\
\hline V. & Koromné Fenyvesi Rózsa & $1719(59,75)$ & Haág Zalán & $1258(37,98)$ \\
\hline VI. & Dr. Kovács Tamás & $1721(50,48)$ & Halkó Pál & $1337(39,2)$ \\
\hline VII. & Szécsényi Rózsa & $2519(66,59)$ & $\begin{array}{l}\text { Dr. Tímárné } \\
\text { Horváth Magdolna }\end{array}$ & $1076(28,44)$ \\
\hline VIII. & Dr. Kozma József & $1969(67,97)$ & Molnár István & $767(26,48)$ \\
\hline IX. & Molnár Zoltán & $1970(62,62)$ & Kárpáti Zoltán & $936(29,75)$ \\
\hline X. & Dr. Binszki József & $1750(58)$ & Szegedinszki Krisztián & $1155(38,28)$ \\
\hline XI. & Hekáné dr. Szondi Ildikó & $1451(54,49)$ & Berniczei-Roykó Ádám & $1007(37,81)$ \\
\hline XII. & Szénási Róbert & $2128(61,18)$ & $\begin{array}{l}\text { Sebőkné } \\
\text { Dobos Zsuzsanna }\end{array}$ & $1032(29,67)$ \\
\hline XIII. & Mészáros Tamás & $1917(64,88)$ & Szente László & $817(27,56)$ \\
\hline XIV & Tóth Károly & $2027(63,13)$ & Bednár László & $957(29,8)$ \\
\hline XV. & Fehér Attila & $1186(37,18)$ & Kothencz János & $1963(61,54)$ \\
\hline XVI. & Nagy Sándor & $2076(65,34)$ & Chovanecz Kata & $1021(32,14)$ \\
\hline XVII. & Urbán Tamás & $1771(55,99)$ & Fekete György & $830(26,24)$ \\
\hline XVIII. & Mihálik Edvin & $1876(56,75)$ & Német Ferenc & $1302(39,38)$ \\
\hline XIX. & Joób Márton & $2188(56,15)$ & Berta József Róbert & $1529(39,2)$ \\
\hline XX. & Avramov András & $2137(52,47)$ & Rózsavölgyi József & $1650(40,51)$ \\
\hline Forrán & & & \\
\hline
\end{tabular}

Forrás: saját szerkesztés

A kompenzációs listáról a töredékszavazatok ${ }^{3}$ alapján a FIDESZ-KDNP 7 jelöltet juttathatott be a képviselőtestületbe (Bartók Csaba, Chovanecz Kata, Haág Zalán, Halkó Pál, Korponyai Ernő, Dr. Németh László, Tápai László). Egy hely jutott listáról 1688 töredékszavazattal az FVSZ-Magyar Egyesületnek is, amit Dr. Szabó Bálint kapott meg, aki egyébként a polgármesterség mellett a XVII. kerületben elindulva 431 $(13,63 \%)$ voksot szerzett, amivel döntő szerepet játszott a kompenzációs mandátum megszerzésében. Lauer István és Dr. Bartha László is indult kerületi jelöltként. Előbbi 413 (12,55\%) voksot szerzett abban a kerületben, melyet 2014-ben 1428 $(48,87 \%)$ szavazattal nyert meg. Dr. Bartha László 91 (2,34\%) vokshoz jutott a XIX.

${ }^{3}$ A töredékszavazatok az egyéni választókörzetekben a mandátumhoz nem jutó jelöltek szavazatait jelentik, amelyek alapján történik a kompenzációs listás helyek elosztása. 


\section{TEMATIKUS TANULMÁNYOK - Önkormányzati választások elméletben és gyakorlatban}

kerületben. A Tisza koalíció 1403 töredékszavazata nem volt elegendő kompenzációs mandátum megszerzéséhez.

Az önkormányzati választásokon elért eredményeket a vegyes rendszert alkalmazó 10000 lakosnál nagyobb városokban az egyéni kerületekben elért eredmények összeadásával tudjuk a legpontosabban megadni (Republikon 2014). Így az Összefogás nevű ernyőszervezet 37290 szavazatot szerzett, a FIDESZ-KDNP jelöltjei 24124 voksot kaptak. Ez azt jelenti, hogy Dr. Botka László mintegy 3500 vokssal kapott többet, mint az őt támogató koalíció, míg Nemesi Pál körülbelül 450 szavazattal hozott többet az őt támogató pártszövetségnél. A szavazatarányok alapján Szegeden az Összefogás 57,81\%-ot szerzett, a FIDESZ-KDNP 37,39\%-hoz jutott. A választás eredményeként létrejövő új képviselőtestületben az Összefogás Szegedért Egyesület tizenkilenc, a FIDESZ-KDNP kilenc, az FVSZ-Magyar Egyesület egy taggal képviselteti magát. A testület több mint fele, tizenöt képviselő újonnan került be a testületbe.

A választási eredmény elemzéséhez, következtetések levonásához közelebb jutunk, ha összevetjük a 2018-as parlamenti, a 2019. májusi európai parlamenti és a 2014-es önkormányzati választás szegedi eredményeivel (Böhm 2006). Természetesen figyelembe kell venni, hogy a szubnacionális, nacionális és szupranacionális választás jelentős különbségeket mutat. A három választás tétje, jelentősége nem azonos súlyú, eltérő a részvétel mértéke, a választók motiváltsága, a pártok választási stratégiája, taktikája, kampánya, a választópolgárok preferenciáinak alakulása. A parlamenti és európai választáson a pártelkötelezettségnek, az önkormányzatin a jelöltek személyének jelentősebb szerepe van. A háromféle választás teljesen különböző választási rendszerrel is történik. Mindezek figyelembevételével kell az adatokból következtetéseket levonni. A parlamenti választás két szegedi választókerületének eredményét együtt, a hozzájuk kapcsolt települések adatainak leválasztásával vesszük figyelembe. Az európai parlamenti választás listás, a pártlistákra leadott voksok jelzik a szegediek pártpreferenciáit. Mindezek a képviselőjelölteknek a 2014-es és az 1. táblázatban bemutatott, 2019-es önkormányzati választáson elért összesített eredményeivel állíthatók párhuzamba. 
www. metszetek.unideb.hu

TEMATIKUS TANULMÁNYOK - Önkormányzati választások elméletben és gyakorlatban

2. táblázat. Részvételi adatok

\begin{tabular}{|c|c|c|c|c|}
\hline & $\begin{array}{c}\text { Parlamenti } \\
\text { választás } \\
\mathbf{2 0 1 8}\end{array}$ & $\begin{array}{c}\text { Európai } \\
\text { parlamenti választás } \\
\mathbf{2 0 1 9}\end{array}$ & $\begin{array}{c}\text { Önkormányzati } \\
\text { választás } \\
\mathbf{2 0 1 4}\end{array}$ & $\begin{array}{c}\text { Önkormányzati } \\
\text { választás } \\
\mathbf{2 0 1 9}\end{array}$ \\
\hline Országos részvétel & $69,73 \%$ & $43,58 \%$ & $44,3 \%$ & $48,58 \%$ \\
\hline Szegedi részvétel & $\begin{array}{c}72,41 \% \\
(94685)\end{array}$ & $45,45 \%(59744)$ & $\begin{array}{c}46,7 \% \\
(64325)\end{array}$ & $\begin{array}{c}51,4 \% \\
(68795)\end{array}$ \\
\hline
\end{tabular}

Forrás: saját szerkesztés

A részvételi adatokból kiolvasható, hogy Szegeden minden alkalommal 2-3\%-kal nagyobb volt az aktivitás az országosnál. A két önkormányzati választás összevetése, a csaknem 5\%-os (4470) különbség pedig azt mutatja, hogy a választók helyileg is nagyobb téttel bírónak érezték a választást, mint korábban. Abból, hogy a győztes 3000, a vesztes pedig 1000 vokssal kapott többet, mint 2014-ben, megállapítható, hogy a plusz voksok mintegy háromnegyede a hivatalban lévő polgármesterhez került. Mivel körülbelül ennyit kapott az LMP és a Jobbik polgármesterjelöltje 2014ben, a polgármester-választáson működőnek tűnik az átszavazás.

3. táblázat. Eredmények

\begin{tabular}{|c|c|c|c|}
\hline $\begin{array}{l}\text { Parlamenti } \\
\text { választás } \\
2018 \\
\end{array}$ & $\begin{array}{c}\text { Európai } \\
\text { parlamenti választás } \\
2019\end{array}$ & $\begin{array}{c}\text { Önkormányzati } \\
\text { választás } \\
2014 \\
\end{array}$ & $\begin{array}{c}\text { Önkormányzati } \\
\text { választás } \\
2019 \\
\end{array}$ \\
\hline $\begin{array}{c}\text { MSZP, Párbeszéd } \\
\text { 43,9\% (39 079) }\end{array}$ & $\begin{array}{l}\text { MSZP, Párbeszéd } \\
\text { 18,57\% (11 042) }\end{array}$ & & \\
\hline $\begin{array}{c}\text { Jobbik } \\
10,645 \%(9433)\end{array}$ & $\begin{array}{c}\text { Jobbik } \\
3,21 \%(1907)\end{array}$ & $\begin{array}{c}\text { Jobbik } \\
6,19 \%(3971)\end{array}$ & \\
\hline $\begin{array}{c}\text { LMP } \\
4,7 \%(4127\end{array}$ & $\begin{array}{c}\text { LMP } \\
2,23 \%(1387)\end{array}$ & $\begin{array}{c}\text { LMP } \\
7,92 \%(5078)\end{array}$ & \\
\hline $\begin{array}{c}\text { Momentum } \\
1,895 \%(1668)\end{array}$ & $\begin{array}{c}\text { Momentum } \\
12,92 \%(7860)\end{array}$ & & \\
\hline \multirow[t]{2}{*}{$\begin{array}{c}\text { A 2019-es } \\
\text { összefogás pártjai } \\
61,14 \% \text { (54 307) }\end{array}$} & $\begin{array}{c}\text { Demokratikus Koalíció } \\
14,5 \%(8623)\end{array}$ & $\begin{array}{l}\text { MSZP-DK-Együtt- Párbe- } \\
\text { széd-Szegedért Egyesület } \\
\text { 48,02\% (30 782) }\end{array}$ & $\begin{array}{c}\text { Összefogás Szegedért } \\
\text { Egyesület } \\
57,81 \% \text { (37 290) }\end{array}$ \\
\hline & $\begin{array}{c}\text { A 2019-es összefogás pártjai } \\
51,43 \% \text { (30 819) }\end{array}$ & $\begin{array}{c}\text { A 2019-es összefogás } \\
\text { pártjai } \\
62,13(39381) \\
\end{array}$ & \\
\hline \multirow[t]{4}{*}{$\begin{array}{l}\text { FIDESZ-KDNP } \\
38,84(33886)\end{array}$} & $\begin{array}{l}\text { FIDESZ-KDNP } \\
40,76 \%(24236)\end{array}$ & $\begin{array}{l}\text { FIDESZ-KDNP } \\
35,85 \% \text { (22 981) }\end{array}$ & $\begin{array}{l}\text { FIDESZ-KDNP 37,39\% } \\
(24124)\end{array}$ \\
\hline & $\begin{array}{c}\text { Magyar Kétfarkú Kutya Párt } \\
\text { 3,80\% (2260) }\end{array}$ & $\begin{array}{c}\text { Egyéb } \\
2 \%(1282)\end{array}$ & \\
\hline & $\begin{array}{c}\text { Mi Hazánk } \\
\text { 3,62\% (2151) } \\
\end{array}$ & & \\
\hline & $\begin{array}{l}\text { Munkáspárt } \\
\text { 0,3\% (179) }\end{array}$ & & \\
\hline
\end{tabular}

Forrás: saját szerkesztés 
A kormánypárt és az ellenzék szavazatarányának alakulását a négy választáson elemezve a következőket állapíthatjuk meg. A FIDESZ-KDNP a tisztán listás, a pártpreferenciákat legegyértelműbben tükröző európai parlamenti választáson érte el a legjobb eredményt, de ez is mintegy 10\%-kal elmaradt az ellenzék pártjaitól. Az is látszik, hogy az 5\%-kal nagyobb részvételü 2019. októberi választáson szinte pontosan ugyanannyi voksot kapott, mint 2019 májusában. Tavaszhoz képest tehát nem tudott több szavazót megszólítani, illetve a helyi preferenciák felülírták a pártszimpátiát. A parlamenti választáshoz képest mindkét önkormányzati választáson gyengébb eredményt ért el, főleg 2014-ben. 2019-ben viszont csak 1,5\%-kal maradt el tőle, és ugyanennyivel növelte 2014-es támogatottságát. A kormánypárt tehát jelentős, stabil, kismértékben ingadozó (35,85\% és 40,76\% között) szegedi szavazótáborral rendelkezik, amely azonban jelentős mértékben elmarad országos támogatottságától. Mindegyik esetben az ellenzék összességében nagyobb támogatást kapott, a legnagyobbat 2014-ben, a legkisebbet az európai parlamenti választáson.

Az ellenzéki szavazótábor mozgása, szerkezete és belső átrendeződése is nyomon követhető a négy választás vizsgálata alapján. A belső átrendeződést elsősorban a parlamenti, az európai és a 2014-es önkormányzati választás számai jelzik. A 2019. októberi eredményekkel kiegészítve kaphatunk képet arról, hogy múködött-e az átszavazás. 2018-ban a koordinált indulás jegyében a Demokratikus Koalíció nem indított jelölteket Szeged két választókerületében, a Momentum új pártként jelentkezett, a Jobbik és az LMP külön indult. Az MSZP, Párbeszéd erős jelöltjeinek köszönhetően kiemelkedően, az országos tendenciával szembemenve szerepelt. A Jobbik 2014 októberéhez képest jelentősen javított, az LMP viszont gyengült. Mindkettő követte az országos helyzetüket. A Momentum még alig volt jelen a városban. A 2019-es tavaszi eredmények azt mutatták, hogy ekkorra a szegedi ellenzéki pártok erőviszonyai is megváltoztak. A Demokratikus Koalíció szerepelt a legjobban, és a Momentum is megelőzte az MSZP-Párbeszéd pártszövetséget. A Jobbik és az LMP tovább gyengült. Mindez alapvetően megváltoztatta a 2019-es önkormányzati választásra kialakítandó ellenzéki együttműködés kereteit, megvalósítását. Az együttműködés meghatározó elemévé a pártokon felülálló ernyőszervezet, az Összefogás Szegedért Egyesület lett, amelynek a polgármesterjelöltje Dr. Botka László, aki személyével is jelezte, hogy nem pártjelölt, hanem a szegediek jelöltje. A nevével fémjelzett képviselőjelöltek közül az MSZP 7, a DK 4, a Momentum 3, a Jobbik1, az LMP 1, az Összefogás Szegedért Egyesület 1 jelöltet adott, 3 pedig az Összefogás közös jelöltje volt. A kampányban és a szavazólapon azonban - egy kivétellel ${ }^{4}$ - mindegyik a hat szervezet közös jelöltjeként jelent meg.

A 2019-es teljeskörű ellenzéki összefogás pártjaira eső szavazatarányok 51,43 és 62,13\% között mozogtak a négy választáson. A legkisebb az EP, a legnagyobb a 2014-es önkormányzati választáson volt, de a parlamenti voksolás esetében is 60\%-

${ }^{4}$ Joób Márton csak az Összefogás Szegedért Egyesület jelöltje volt. 


\section{TEMATIKUS TANULMÁNYOK - Önkormányzati választások elméletben és gyakorlatban}

on felüli az eredmény. A Jobbik és az LMP nélkül 2014-ben 48,02, 2018-ban, illetve 2019 májusában a Jobbik, az LMP és a Momentum nélkül 43,9, illetve 33,07\% volt a szavazatarányuk. Együttesen tehát minden alkalommal 50\% feletti eredményt értek el, a Jobbik és az LMP nélkül viszont egyszer sem tudtak 50\% fölé kerülni. Az ellenzéki pártok mindegyikének érdekében állt tehát helyileg is az együttmúködés valamilyen formájának prioritássá válása, megvalósítása. Külön-külön ugyanis egyikük sem válhatott meghatározó erővé. A város érdekében az együttműködés szükségessége felül tudta írni a pártérdekeket, és ezt személyileg is megalapozta a polgármester és a képviselőtestület frakciója. Az ellenzéki városvezetés 2010 -től folytatott politikája hitelesíteni tudta ezt az összefogást. Az persze kérdéses volt, hogy a szegedi polgárok visszaigazolják-e 2019-ben a korábbinál szélesebb, az MSZP-től a Jobbikig terjedő együttmúködést.

A polgármesterválasztáson - ahogy fentebb megállapítottuk - jelentősebb átszavazás valószínűsíthető, a 60,56\%-os szavazatarányban a Jobbik és az LMP 2014-es és 2018-as szavazói egy részének a voksai is benne lehetnek (nélkülük 48, illetve $42 \%$ volt az ellenzék eredménye). Az Összefogás Szegedért Egyesület választókörzeti 57,81\%-os eredménye - ha kisebb mértékben is - de szintén azt mutatja, hogy az LMP és a Jobbik szavazói közül is voksolhattak az Összefogás jelöltjeire. Mintegy 4500-zal volt nagyobb a részvétel 2019-ben, mint 2014-ben, a két összefogás szavazatai között pedig 6500 a különbség. A külön induló Jobbikra és az LMP-re összesen 9000-en szavaztak 2014-ben. Ezekből a számokból csak feltételezhető, hogy egy kisebb mértékű átszavazás a képviselőjelöltek esetében is történt. Egy konkrét példát ennek igazolására fel lehet hozni. 2014-ben a Jobbik színeiben induló Komjáti Zoltán 200 (6,84\%) voksot kapott a II. választókerületben. 2019-ben viszont az Összefogás jelöltjeként 1362 (40,92\%) vokshoz jutott az I. kerületben - ahol 2014-ben az Öszszefogás és a Jobbik jelöltje együtt 1319 (45,02\%) szavazatot kapott - egyedül tehát többet, mint a két jelölt 5 évvel korábban.

\section{Összegzés}

A 2019-es önkormányzati választáson elért minden korábbinál nagyobb arányú ellenzéki győzelem felveti azt a kérdést, milyen okai vannak annak, hogy a szociodemográfiai összetétel és a tradíciók alapján inkább konzervatív-jobboldalinak tartott város (Hegedûs 2007) tartósan baloldali-liberális városvezetésnek ad bizalmat. A 2019-es eredmény több tényező hatásának köszönhető. Elsőként az ellenzék minden korábbinál szélesebb és hatékonyabb együttműködése említhető meg. Ennek megvalósítása Szegeden már 2010-ben elkezdődött, az összefogás tehát hiteles és sikeres volt, amire alapozva lehetett tovább építeni. Ezt ezúttal az országos együttmüködés hatékonysága is alátámasztotta. Így az átszavazás is részben megvalósulhatott, kevésbé okozott nehézséget a választóknak, és új szavazókat is meg lehetett 
szólítani. Ezt az is bizonyítja, hogy a FIDESZ támogatottsága nem csökkent a városban, mégis nőtt a polgármesterre szavazók aránya, és a Jobbik és LMP nélküli 2014-es összefogáshoz képest, a két párt meggyengülése ellenére a polgármester vezette Összefogás Szegedért Egyesület támogatottsága is emelkedett.

Az önkormányzati választáson erősen jelentkező inkumbencia - azaz a hivatalban lévő településvezetés helyzeti előnye - Szegeden fokozottabban nyilvánulhatott meg. A választók és a város ellenszélben történő fejlődése visszaigazolták, hogy nemcsak választási szlogennek bizonyult az, hogy a város érdekében történő működés mindent felülír. A FIDESZ ezt kétségbe vonó kampánya nem volt képes azt hitelteleníteni.

Nem lehet figyelmen kívül hagyni a kampány hatását - annak tudatában sem -, hogy a kampány szerepe csökkenővé vált a korábbiakhoz képest. A jelentős mértékű aszimmetria a szegedi helyzetben kontraproduktívnak bizonyult. A kampány egyik oldalon - kisebb lehetőségekkel is rendelkezve - visszafogottabb, mérsékeltebb, békét, biztonságot, nyugalmat sugárzónak tűnt, míg a másik oldal kampánya semmilyen eszköztől sem visszariadva, konfliktusos, a várost csatatérré változtató helyzetet teremtett és vetített előre. A valóságnak ellentmondó kampánytematizálás is inkább ellentétes hatást válthatott ki.

A várospolitika több ciklus óta tartó kiemelése a pártpolitikai csatározásokból szintén a regnáló városvezetés pozícióját erősítette. Ezen Botka László elbukott miniszterelnök-jelölti kísérlete sem változtatott, pedig a kampányban felhasználták ellene (Délmagyarország, 2019. október 2.). Elért eredménye azt mutatja, hogy az MSZP vezetésétől, így a pártjától való eltávolodása még meg is erősítette helyileg. ${ }^{5}$

A választási eredmény elemzésénél nem lehet elmenni a személyi tényező mellett. Botka Lászlónak kiemelkedő szerepe van a szegedi helyzet alakulásában. Az ellenzék tartós sikere nem utolsósorban neki köszönhető. 1994 óta három parlamenti választást és öt polgármester-választást nyert meg Szegeden. 2010-től kezdve mindig sokkal jobban szerepelt pártjánál. 2019-ben minden eddiginél több, először 40 000-nél és 60\%-nál több szavazattal győzött. Eszerint a megkopásáról, meggyengüléséről szóló kampányszlogeneket a választók nem igazolták vissza. A nevével fémjelzett képviselőjelölti listák váratlan és elsöprő sikere a két legutóbbi választáson is elsősorban az ő személyének köszönhető. Ez néhány példával jól illusztrálható. 2014-ben az összefogás szinte teljesen ismeretlen, új jelöltjei a FIDESZ-KDNP olyan emblematikus, és korábban győztes jelöltjeit verték meg, mint Gyimesi László (a FIDESZ volt helyi elnöke), Hűvös László, Haág Zalán, Farkasné Pocsai Blanka, Rózsavölgyi József. Ez akkor történt, amikor országosan, a nagyvárosokban is teljes kormánypárti győzelem született. 2019-ben a legjobb példa erre Lauer István szereplése. Ố 2014-ben 48,87\%-kal (1428) szavazattal nyerte meg kerületét.

\footnotetext{
${ }^{5}$ Ez az eltávolodás a választás után szakításhoz, az MSZP-ből való kilépéshez vezetett.
} 
Ugyanitt 2019-ben függetlenként, korábbi támogató szervezetével szembefordulva 12,55\%-ot (413) ért el. Az Összefogás Szegedért Egyesület új, szinte ismeretlen jelöltjei is meggyőző fölénnyel nyertek a II., III., V., VI., IX., XVII., XVIII és XX. választókerületekben. A legyőzött ellenfelek között ezúttal is szerepeltek korábban már indult, illetve a politikában ismertebb jelöltek, mint Korponyai Ernő (a Fidelitas helyi elnöke), Haág Zalán, Halkó Pál, Német Ferenc, Rózsavölgyi József. A IX. kerületben például a két ismeretlennek számító jelölt közül Molnár Zoltán (Összefogás) 62,62\% (1970), Kárpáti Zoltán (FIDESZ-KDNP) 29,75\% (936) voksot kapott. Ezek a példák azt igazolják, hogy Botka László személye, pártjának meggyengülése ellenére, pártállástól függetlenül képes a szegedi választópolgárok többségét nemcsak maga, hanem a nevéhez kapcsolható jelöltek támogatottságát is biztosítani.

Az elmondottak alapján megkockáztatható az a kijelentés, hogy Szegeden a helyi helyzet, a helyi politikai tér játszott döntő szerepet a 2019-es önkormányzati választás eredményében. Ez azt jelenti, hogy a nagyvárosokban megnyilvánuló kormánykritikus hangulat erősödése, valamint a Borkai ügy ${ }^{6}$ csekély szerepet játszhatott a választópolgárok döntésében.

A választási eredményt az új összetételű testület működése, az Összefogás Szegedért Egyesület színeiben bejutó városatyák együttműködése, a kisebbségben lévő kormánypárti frakciók magatartása fogja meghatározni, és így hitelesíteni. Azt a jövő fogja eldönteni, hogy a megváltozott helyzet, az ellenzék Budapesten és a nagyvárosokban történő előretörése milyen hatással lesz Szeged eddigi kivételes helyzetére.

\section{Irodalom}

Bőhm A. (2006): Az önkormányzati választások a parlamenti választások tükrében.

In: Bőhm, A. (szerk.): A helyi hatalom és az önkormányzati választások Magyarországon 1990-2002. MTA Politikai Tudományok Intézete, Budapest, 11-18.

Délmagyarország, 2019. augusztus 24.

Délmagyarország, 2019. szeptember 3.

Délmagyarország, 2019. szeptember 7.

Délmagyarország, 2019. szeptember 14.

Délmagyarország, 2019. szeptember 20.

Délmagyarország, 2019. október 4.

Délmagyarország, 2019. október 12.

${ }^{6}$ A Borkai Zsolt győri polgármesterről megjelent videó a felmérések és elemzések szerint hozzájárult ahhoz, hogy Budapesten és a 10000 lakosnál nagyobb városokban felerősítette a kormánykritikus hangulatot, és mozgósító hatása volt protesztszavazatok leadására. 


\section{TEMATIKUS TANULMÁNYOK - Önkormányzati választások elméletben és gyakorlatban}

Fábián Gy. (2013): Önkormányzati választások Szegeden, 1990-2010. Ünnepi kötet Dr. Blazovich László egyetemi tanár 70. születésnapjára. Acta Universitatis Szegediensis. Acta Iuridica Et Politica. Tomus LXXXV., Szeged, 223-237.

Hegedűs G. (2007): A választási aktivitás és az életminőség területi különbségeinek néhány összefüggése Szegeden. Földrajzi értesítő, LVI. évf. 1-2. füzet. 113-123.

Reif, K. - Schmitt, H. (1980): Nine second order elections - A comparative framework for the analysis of European election results. European Journal of Political Research, 8(1) 3-44.

Republikon (2014): Hogyan lehet országosan összegezni az önkormányzati eredményeket. https://republikon.hu/media/18009/onkval_meres_modszertan_3.pdf

\section{Elektronikus források:}

https://www.valasztas.hu

https://szegedma.hu

szeged.hu 